http://dx.doi.org/10.18778/1508-1117.26.08

Jolanta Jakóbczyk-Gryszkiewicz

\title{
IMIGRANCI SPOZA UE W POLSCE, LODZI I REGIONIE ŁÓDZKIM
}

Zarys treści Artykuł omawia rezultaty badań prowadzonych w Łodzi i regionie łódzkim w ramach grantu UE nt. Diversity Improvement as a Viable Enrichment Resource for Society and Economy. Badania przeprowadzono w różnych instytucjach zajmujących się cudzoziemcami w Polsce i regionie, w przedsiębiorstwach zatrudniających imigrantów (10 przedsiębiorstw - public, profit i non profit) oraz w organizacjach wolontariackich, w których takie osoby działają.

Ogólnym celem projektu było sprawdzenie, czy funkcjonuje w Polsce i regionie skuteczny model integracji imigrantów spoza UE, zbadanie czy istnieją praktyki wspierające ich równe traktowanie oraz skuteczna waloryzacja ich umiejętności, wiedzy i kompetencji. Wyniki badań stanowiły podstawę do wskazania co i jak należy poprawić w działaniach wobec imigrantów. Celem niniejszej pracy była prezentacja idei i wyników tego projektu.

Jak wykazały badania, obecność imigrantów spoza UE w regionie łódzkim jest marginalna. Cudzoziemcy koncentrowali się głównie w Łodzi i jej obszarze metropolitalnym. Ich struktura narodowościowa okazała się podobna jak w całej Polsce - najliczniej reprezentowani byli przybysze z Ukrainy (25\% ogółu imigrantów), Białorusi i innych byłych krajów socjalistycznych oraz z Azji (w tym Chińczycy 10\% ogółu). Przeważały osoby zatrudnione na stanowiskach nie wymagających wysokich kwalifikacji. Imigranci przebywający w regionie łódzkim, w zależności od kraju pochodzenia, pracowali głównie w przemyśle wytwórczym, budownictwie i handlu.

Wobec aktualnych potrzeb w sytuacji demograficznej starzejącego się społeczeństwa polskiego, jak również takich czynników zewnętrznych, jak np. wojna i kryzys gospodarczy na Ukrainie, spodziewany będzie większy napływ imigrantów spoza UE.

Generalnym wnioskiem z badań jest wskazanie, że należy udoskonalić istniejące przepisy prawne oraz stworzyć nowe regulujące w lepszy sposób problem pobytu imigrantów spoza UE, zasad uznawania ich kwalifikacji zawodowych oraz pozyskiwania pracy w Polsce.

Słowa kluczowe Imigracja, imigranci, imigranci spoza UE, umiejętności, wiedza i kompetencje imigrantów, Unia Europejska, Polska, Łódź, region łódzki. 


\section{Problem badawczy i cele badań}

Wobec postępującego starzenia się społeczeństw w krajach UE, napływ imigrantów spoza wspólnoty poszukujących pracy jest jednym ze sposobów rozwiązania problemów na rynku pracy. Otwarcie polskiego rynku pracy dla cudzoziemców spoza UE również staje się istotne ze względu na sytuację demograficzną - starzenie się społeczeństwa oraz bardzo niski, a do niedawna ujemny przyrost naturalny.

Badania dotyczące obecności cudzoziemców spoza UE na polskim rynku pracy odnoszą się przede wszystkim do analiz wielkości napływu oraz struktury zatrudnienia cudzoziemców. Najwięcej prac dotyczy najliczniejszej ich grupy w Polsce, a więc Ukraińców. Obecności Ukraińców na polskim rynku pracy poświęcony jest m.in. raport J. Korczyńskiej i M. Duszczyka (2005) Zapotrzebowanie na prace obcokrajowców w Polsce - próba analizy $i$ wniosków dla polityki migracyjnej, raport A. Grzymały-Kazłowskiej(2002) Wpływ migracji zagranicznych w Warszawie na sytuację na stołecznym rynku pracy, czy książka pod redakcją S. Golinowskiej (2004) Popyt na pracę cudzoziemców. Polska i sąsiedzi. Jednym $\mathrm{z}$ najnowszych opracowań poświęconych imigrantom z Ukrainy jest praca pt. Migracje obywateli Ukrainy do Polski w kontekście rozwoju społeczno-gospodarczego: stan obecny, polityka, transfery pieniężne Z. Brunarskiej, M. Grotte i M. Lesińskiej (2012).

Wskazane publikacje analizują polski rynek pracy, na którym funkcjonują migranci z Ukrainy, w świetle dostępnych statystyk oraz szacunków pracy nierejestrowanej i na ich podstawie próbują określić zarówno rzeczywiste zapotrzebowanie na pracę imigrantów w Polsce (lub w ujęciu regionalnym), jak i przewidywane skutki zmian liczby obcokrajowców na tym rynku. Niektóre opracowania zajmują się migracją kobiet. Ukrainkom i ich pozycji ekonomicznej na polskim rynku pracy poświęcony jest raport W. Kloc-Nowak (2007) pt. Funkcjonowanie imigrantek z Ukrainy na polskim rynku pracy - sytuacja obecna i rekomendacje dla spoleczeństwa przyjmującego.

Spośród prac zajmujących się innymi imigrantami spoza UE wymienić należy także poświęcone Wietnamczykom, jak np. Wietnamczycy w Polsce. Izolacja czy integracja T. Halik i E. Nowickiej (2002). Autorki wskazują na powolną integrację Wietnamczyków, znaczącą przewagę małżeństw w obrębie tej grupy etnicznej oraz poleganie na własnej grupie etnicznej w zakresie zatrudnienia. Problematykę nielegalnego zatrudniania obywateli Chin i Wietnamu oraz rozwoju enclave economy prezentuje praca N. Klorek i M. Szuleckiej (2013) poświęcona funkcjonowaniu jednego $\mathrm{z}$ największych centrów handlu bazarowego w okolicach Warszawy: Migranckie instytucje ekonomiczne i ich wpływ na otoczenie. Przykład centrów handlowych w Wólce Kosowskiej. 
Analizie obecności imigrantów na polskim rynku pracy oraz warunków zatrudnienia cudzoziemców w Polsce poświęcone są prace: Transformacja nieoczywista. Polska jako kraj imigracji (Górny i in. 2010), Polska polityka imigracyjna a rynek pracy (Duszczyk 2012), Imigranci z krajów trzecich na polskim rynku pracy (Polakowski 2010), a także Ziemia obiecana. Warunki pracy cudzoziemców w Polsce (Klaus 2011). Prace te jednoznacznie wskazują na znaczną liczbę imigrantów spoza UE pracujących w Polsce, w tym nielegalnie.

W 2011 roku przeprowadzono unikalne w Polsce badania w ramach projektu UE, przy wsparciu Europejskiego Funduszu Społecznego, pod nazwą Diversity Index. Ich efekty opublikowano w książce Zarządzanie różnorodnościa w miejscu pracy. Raport z I edycji Barometru Różnorodności (2014). Zastosowano w nich metodę indywidualnych wywiadów telefonicznych na reprezentacyjnej grupie 800 dużych i średnich przedsiębiorstw w całej Polsce. Wyniki badań wskazały, że jedynie niecałe $70 \%$ firm spotkało się z podejściem zwanym zarządzaniem różnorodnością. Znajomość samego pojęcia wykazało 69\% firm dużych i 62\% średnich.

Idea zarządzania różnorodnością dotarła do Polski z dużym opóźnieniem w stosunku do państw Europy Zachodniej i USA. Nie jest to pojęcie powszechnie znane. W przedsiębiorstwach i instytucjach pracodawcy najpierw skupiali uwagę na równych szansach w zatrudnianiu kobiet i mężczyzn, zatrudnianiu osób niepełnosprawnych, a dopiero od niedawna na zarządzaniu różnorodnością w zakresie zatrudniania obcokrajowców.

W latach 2014-2015 zespół w składzie: J. Jakóbczyk-Gryszkiewicz, S. Marcińczak, M. Sztybel-Boberek i A. Wolaniuk z Zakładu Urbanizacji Przestrzeni Instytutu Geografii Miast i Turyzmu WNG brał udział w grancie UE nt. Diversity Improvement as a Viable Enrichment Resource for Society and Economy (Zarzadzanie różnorodnościa w sferze społecznej i gospodarczej). Autorzy reprezentowali Polskę, a konkretnie Łódź i region łódzki, w gronie 14 innych państw unijnych (Jakóbczyk-Gryszkiewicz, Marcińczak, Sztybel-Boberek, Wolaniuk 2015).

$\mathrm{W}$ ramach grantu prowadzono badania $\mathrm{w}$ wybranych instytucjach różnych szczebli zajmujących się cudzoziemcami spoza UE (zwanych obywatelami państw trzecich) w Polsce, w przedsiębiorstwach zatrudniających imigrantów, jak również w organizacjach pozarządowych, w których takie osoby działają. Nie objęły one cudzoziemskich studentów uczących się w polskich uczelniach.

Głównym zadaniem projektu było określenie, czy w Polsce (w tym w Łodzi i w regionie łódzkim) istnieją wśród pracodawców praktyki wspierające równe traktowanie imigrantów, a także waloryzację ich umiejętności, wiedzy i kompetencji oraz jak postępuje integracja cudzoziemców spoza UE. Wyniki badań stanowiły podstawę do wskazania co i jak należy poprawić w działaniach wobec imigrantów. Celem niniejszej pracy była prezentacja idei i wyników tego projektu. 


\section{Imigracja w Polsce po 1989 roku}

Po 1989 roku Polska stała się krajem tranzytowym lub docelowym dla niektórych kategorii migrantów i grup narodowościowych. Na początku lat 90. XX wieku byli to przede wszystkim turyści - od 10 do 90 mln osób w 1999 roku (Okólski 2011). W większości można ich było określić jako tzw. pseudoturystów, przyjeżdżających do Polski w celach handlowych (handel bazarowy) i na krótko w celu podjęcia dorywczej pracy.

Mimo otwarcia granic Polski w 1989 roku rynek pracy dla cudzoziemców był ograniczony w związku z upadkiem wielkich przedsiębiorstw państwowych, głównie przemysłowych. W regionie łódzkim nastąpił upadek tradycyjnego przemysłu włókienniczego i ogromnie wzrosło bezrobocie.

Najliczniej przybywali do Polski mieszkańcy państw powstałych z rozpadu ZSRR, w tym gros stanowili Ukraińcy. Osoby te stały się pionierami imigracji dzięki wielokrotnym wizytom w Polsce i coraz lepszemu poznawaniu polskich realiów życia i funkcjonowania, głównie w szarej strefie. Z czasem podejmowały zatrudnienie.

Wraz z przystąpieniem do Unii Europejskiej wzrosła atrakcyjność Polski nie tylko jako kraju tranzytu, ale i miejsca nauki, zatrudnienia i osiedlenia. Ograniczenie barier mobilności po przyjęciu Polski do strefy Schengen dało szansę cudzoziemcom przyjeżdżającym do naszego kraju na pobyty średnio- i długoterminowe, na swobodne przemieszczanie się w ramach tej strefy i prowadzenie różnego rodzaju działalności.

W latach 1990-2010 do Polski przyjechało (i zarejestrowało się) niewiele ponad 130 tys. imigrantów. Docierali oni do Polski z krajów słabiej rozwiniętych, w tym zza wschodniej granicy, a także z Unii Europejskiej i Stanów Zjednoczonych (często były to osoby o polskich korzeniach). Dla porównania $-\mathrm{z}$ Polski w tym czasie (zwłaszcza po wejściu do UE) wyemigrowało około 2 mln młodych osób.

W ślad za zwiększającym się stopniowo napływem imigrantów następowały zmiany w prawodawstwie polskim. W 1991 roku nastąpiło ratyfikowanie przez Polskę konwencji dotyczącej statusu uchodźców (Konwencji Genewskiej) z 1951 roku oraz wprowadzono zmiany w ustawie o cudzoziemcach, regulujące problematykę migracji i uchodźstwa. W 2001 roku został powołany Urząd do Spraw Repatriacji i Cudzoziemców - centralny organ administracji rządowej o szerokich kompetencjach w dziedzinie migracji, azylu i obywatelstwa. W każdym z 16 województw działają Wydziały do Spraw Cudzoziemców.

Masowa emigracja Polaków po 2004 roku przyczyniła się do zmian na polskim rynku pracy. Młodzi Polacy zaczęli masowo wyjeżdżać do pracy na zachód Europy - głównie do Anglii, Irlandii i Holandii, potem zaś do Niemiec. Spowodowało to lukę na polskim rynku pracy, dlatego też od 2005 roku następowała stopniowa liberalizacja przepisów ułatwiających podjęcie imigrantom pracy w Polsce. 
Dane na temat cudzoziemców w Polsce pochodzą z różnych źródeł: narodowych spisów powszechnych 2002 i 2011, ewidencji bieżącej ludności oraz opracowań Urzędu do Spraw Cudzoziemców. Niestety, dane ze spisów powszechnych oraz z ewidencji bieżącej nie oddają w pełni skali imigracji do Polski. W materiałach tych uwzględnieni są jedynie cudzoziemcy przebywający w Polsce na pobyt stały. Podobny problem dotyczy danych z ewidencji bieżącej. Pomimo ograniczeń dane ze spisów i ewidencji są jedynym źródłem informacji o strukturze demograficznej imigrantów.

Pełniejsze dane obrazujące skalę napływu cudzoziemców spoza UE do Polski zostały udostępnione przez Urząd do Spraw Cudzoziemców. Zawierały wszystkie kategorie imigrantów przebywających w Polsce: uchodźców, azylantów, rezydentów innych krajów UE, osoby przebywające na pobyt czasowy oraz na pobyt stały według kraju pochodzenia. Struktura zatrudnienia cudzoziemców według zawodów została opracowana w oparciu o materiały udostępnione przez Ministerstwo Pracy i Polityki Społecznej. Informacje z tego źródła dostępne były w podziale na wykonywany zawód, na wybrane sekcje gospodarki, zezwolenia według czasu trwania i typu pozwolenia, a także liczbę odmów. W badanym regionie łódzkim danych dostarczyły: Urząd Wojewódzki w Łodzi, Powiatowy Urząd Pracy, Wojewódzki Urząd Pracy oraz Wojewódzki Urząd ds. Cudzoziemców.

Dane z NSP 2011 roku ujawniły, że w Polsce przebywało na stałe ok. 63 tys. cudzoziemców, co stanowiło zaledwie ok. 0,2\% stałych mieszkańców Polski. Dla krajów UE średnia przekracza 4\% ogółu. W końcu 2013 roku według danych Urzędu ds. Cudzoziemców, zezwolenie na pobyt w Polsce miało 121219 cudzoziemców, która to populacja stanowiła 0,3\% ludności Polski (Konieczna-Sałamatin 2015).

Najczęściej reprezentowane kierunki napływu imigrantów do Polski w podziale na pobyt czasowy i pobyt stały wskazywały, że są to kraje leżące poza UE. W la-tach 2001-2003 najliczniej reprezentowani byli Ukraińcy, Białorusini i Rosjanie, zaś w okresie 2009-2012 Ukraińcy, Wietnamczycy, Chińczycy i Rosjanie (tab. 1).

Zainteresowanie pobytem w Polsce cudzoziemców systematycznie rosło. Obywatele Ukrainy stanowili w gronie najliczniej prezentowanych imigrantów najczęściej przeszło 50\% udział zarówno w grupie pobytów czasowych, jak i stałych (tab. 1).

Polska, ze względu na depopulację i starzenie się społeczeństwa, potrzebuje chętnych do pracy, łatwo asymilujących się imigrantów. Naturalnymi kandydatami są nasi sąsiedzi Ukraińcy. Z danych rządowych wynika, że legalnie pracuje w kraju 650 tys. Ukraińców, nielegalnie zaś prawdopodobnie kolejne 270 tys. Ambasada Ukrainy w Polsce podała, że tylko w 2015 roku wydano 930 tys. wiz do Polski dla obywateli Ukrainy. Można z dużym prawdopodobieństwem oszacować liczbę Ukraińców w Polsce w 2016 roku (przebywających tu zarówno legalnie, jak i nielegalnie) na blisko 1 mln osób (Raport. Imigranci z Ukrainy ratunkiem dla polskiej demografii 2016). 
Tabela 1

Najliczniej reprezentowane grupy imigrantów* według kraju pochodzenia w Polsce w latach 2001-2012

\begin{tabular}{|c|c|c|c|c|c|}
\hline \multicolumn{3}{|c|}{ Pobyt czasowy } & \multicolumn{3}{|c|}{ Pobyt stały } \\
\hline Obywatelstwo & Liczba osób & \% ogółu & Obywatelstwo & Liczba osób & \% ogółu \\
\hline \multicolumn{6}{|c|}{$2001-2003$} \\
\hline $\begin{array}{l}\text { Cudzoziemcy } \\
\text { ogółem }\end{array}$ & 79002 & - & $\begin{array}{l}\text { Cudzoziemcy } \\
\text { ogółem }\end{array}$ & 3016 & - \\
\hline \multicolumn{3}{|c|}{ Najliczniej reprezentowane obywatelstwa } & \multicolumn{3}{|c|}{ Najliczniej reprezentowane obywatelstwa } \\
\hline Ukraińskie & 19461 & 50,3 & Ukraińskie & 686 & 37,9 \\
\hline Białoruskie & 6316 & 16,3 & Wietnamskie & 436 & 24,1 \\
\hline Rosyjskie & 5367 & 13,9 & Rosyjskie & 305 & 16,9 \\
\hline Niemieckie & 4087 & 10,5 & Ormiańskie & 198 & 11,0 \\
\hline Francuskie & 3492 & 9,0 & Białoruskie & 183 & 10,1 \\
\hline Razem & 38723 & 100,0 & Razem & 1808 & 100,0 \\
\hline \multicolumn{6}{|c|}{ 2009-2012 } \\
\hline $\begin{array}{l}\text { Cudzoziemcy } \\
\text { ogółem }\end{array}$ & 125142 & - & $\begin{array}{l}\text { Cudzoziemcy } \\
\text { ogółem }\end{array}$ & 13704 & - \\
\hline \multicolumn{3}{|c|}{ Najliczniej reprezentowane obywatelstwa } & \multicolumn{3}{|c|}{ Najliczniej reprezentowane obywatelstwa } \\
\hline Ukraińskie & 34988 & 50,7 & Ukraińskie & 6165 & 55,6 \\
\hline Wietnamskie & 10346 & 15,0 & Białoruskie & 2580 & 23,4 \\
\hline Chińskie & 9739 & 14,0 & Rosyjskie & 732 & 6,6 \\
\hline Białoruskie & 8400 & 12,1 & Wietnamskie & 302 & 2,8 \\
\hline Rosyjskie & 5684 & 8,2 & Ormiańskie & 289 & 2,6 \\
\hline Razem & 69157 & 100,0 & Razem & 11078 & 100,0 \\
\hline
\end{tabular}

* uwzględniono jedynie imigrantów przebywających w Polsce na podstawie pozwolenia na pobyt czasowy lub stały.

Źródło: Urząd do Spraw Cudzoziemców.

Jak wynika z przeprowadzonego w styczniu 2016 roku na zlecenie Związku Przedsiębiorców i Pracodawców badania - aż 52\% Polaków odnosi się pozytywnie do przyznania stałego pobytu Ukraińcom przebywającym w Polsce, zaś 28\% jest temu przeciwne (badania Domu Badawczego Maison). Również na pytanie: jakiej narodowości powinniśmy przyjmować imigrantów - na pierwszym miejscu znaleźli się Ukraińcy - wskazało ich aż 33\% badanych. Podobnie przychylni 
Polakom są Ukraińcy - aż 79\% mieszkańców zachodniej Ukrainy deklaruje swoją sympatię do Polaków (Raport. Imigranci z Ukrainy ratunkiem dla polskiej demografii 2016).

Utrzymująca się w Polsce do 2014 roku stopa bezrobocia przekraczająca $10 \%$ nie hamowała wzrostu liczby wydanych cudzoziemcom pozwoleń na pracę (tab. 2). W roku 2014 zezwolenie na zatrudnienie w Polsce otrzymało przeszło 44,5 tys. cudzoziemców. W porównaniu z rokiem 2008 liczba zezwoleń wzrosła przeszło dwukrotnie.

Tabela 2

Liczba zezwoleń na pracę wydana cudzoziemcom w latach 2008-2014 i stopa bezrobocia na koniec roku

\begin{tabular}{|c|c|c|}
\hline Lata & Zezwolenia na prace & Stopa bezrobocia \\
\hline 2008 & 18022 & 9,5 \\
\hline 2009 & 29340 & 12,1 \\
\hline 2010 & 36662 & 12,4 \\
\hline 2011 & 40808 & 12,5 \\
\hline 2012 & 39144 & 13,4 \\
\hline 2013 & 39078 & 13,4 \\
\hline 2014 & 44583 & 11,5 \\
\hline
\end{tabular}

Źródło: Ministerstwo Pracy i Polityki Społecznej, GUS.

Przed 2014 rokiem, aby uzyskać pozwolenie na pracę trzeba było starać się o zgodę na pobyt stały, a następnie o pozwolenie na pracę (możliwe do uzyskania, gdy nie było w Urzędzie Pracy zgłoszeń Polaków na daną ofertę pracy). W maju 2014 roku weszła w życie nowa ustawa o cudzoziemcach skracająca dotychczasowe procedury. Teraz jest to procedura uproszczona - wydaje się łączne zezwolenie na pobyt stały i na pracę.

W porównaniu z 2014 rokiem o 50\% wzrosła liczba wydawanych zezwoleń na pracę. Rok 2015 był rekordowy pod względem liczby wydanych przez wojewodów zezwoleń na pracę cudzoziemców (65786) oraz zarejestrowanych w urzędach pracy oświadczeń o zamiarze powierzenia pracy cudzoziemcowi (782 222) (Biuletyn Migracyjny, czerwiec 2016).

Wciąż jednak najwięcej zależy od pracodawcy, który występuje do Urzędu Pracy wskazując na jakie stanowisko i z jakimi kwalifikacjami zamierza zatrudnić daną osobę oraz podejmuje ostateczną decyzję kogo zatrudnia. Liczba zarejestrowanych oświadczeń pracodawców o zamiarze zatrudnienia obywateli krajów objętych systemem uproszczonym wyniosła w 2011 roku 259777. Dla porównania 
- w roku 2010 było to 180073 oświadczeń. Ponadto wydano 209577 wiz w celu wykonywania pracy. Ponad 93\% otrzymali obywatele Ukrainy, Białorusi i Rosji (wg danych Ministerstwa Pracy i Polityki Społecznej). Przytoczone dane nie obejmują obywateli krajów członkowskich UE i członków ich rodzin, nielegalnych migrantów i cudzoziemców przebywających na podstawie wiz.

Legalne zatrudnienie cudzoziemców w Polsce opiera się przede wszystkim na bezpłatnej uproszczonej procedurze, która pozwala obywatelom sześciu państw - Armenii, Białorusi, Gruzji, Mołdowy, Rosji i Ukrainy - wykonywać pracę w Polsce przez 6 miesięcy w okresie 12 następujących po sobie miesięcy, bez konieczności uzyskania zezwolenia na pracę (Biuletyn Migracyjny, czerwiec 2016).

Największe zapotrzebowanie na pracowników w Polsce występowało w rolnictwie (przeszło 50\%), budownictwie i przemyśle. W tych trzech sektorach oświadczenia o zamiarze powierzenia pracy zajęły przeszło $70 \%$ ofert (tab. 3 ).

Tabela 3

Rozkład branżowy liczby oświadczeń o zamiarze powierzenia pracy cudzoziemcowi zarejestrowanych w 2013 roku

\begin{tabular}{|l|c|c|}
\hline \multicolumn{1}{|c|}{ Branża } & Liczba oświadczeń & \% ogółu \\
\hline $\begin{array}{l}\text { Rolnictwo, leśnictwo, lowiectwo } \\
\text { i rybactwo }\end{array}$ & 118480 & 50,4 \\
\hline Budownictwo & 29734 & 12,6 \\
\hline Przetwórstwo przemysłowe & 17739 & 7,5 \\
\hline Handel hurtowy i detaliczny & 12130 & 5,1 \\
\hline $\begin{array}{l}\text { Gospodarstwa domowe zatrudniające } \\
\text { pracowników }\end{array}$ & 5796 & 2,4 \\
\hline Transport i gospodarka magazynowa & 5548 & 2,3 \\
\hline Zakwaterowanie i gastronomia & 3770 & 1,6 \\
\hline $\begin{array}{l}\text { Działalność profesjonalna, naukowa } \\
\text { i techniczna }\end{array}$ & 1452 & 0,6 \\
\hline Informacja i komunikacja & 686 & 0,3 \\
\hline Działalność finansowa i ubezpieczenia & 671 & 0,3 \\
\hline Opieka zdrowotna i pomoc społeczna & 541 & 0,2 \\
\hline Edukacja & 110 & 0,04 \\
\hline Inne & 38959 & 16,5 \\
\hline
\end{tabular}

Źródło: Ministerstwo Pracy i Polityki Społecznej. 
Koncentracja cudzoziemców w rolnictwie maleje jednak z każdym rokiem i tak w 2015 roku już tylko 35\% oświadczeń dotyczyło rolnictwa. Większego znaczenia nabiera przetwórstwo przemysłowe, działalność profesjonalna, naukowa i techniczna, budownictwo oraz transport i gospodarka magazynowa. Utrzymuje się relatywnie wysoka liczba zezwoleń wydawanych w sektorze usług domowych, zaś spada udział zezwoleń dla handlu hurtowego i detalicznego. Podobnie jak w poprzednich latach, największa liczba oświadczeń i zezwoleń na pracę przypada na województwo mazowieckie. Znacząco rośnie udział obywateli Ukrainy (Biuletyn Migracyjny, czerwiec 2016).

Dostępne dane nie pozwalają ocenić całości zjawisk imigracyjnych w Polsce. Dotyczy to w szczególności zjawiska migracji nielegalnej, w tym nielegalnego zatrudnienia (Okólski 2011). Na wyraźnie większe rozmiary napływu do Polski legalnej migracji wskazują choćby dane o skali ruchu granicznego. Symptomatyczny jest także sukces programu zatrudnienia sezonowego obywateli państw ościennych (na podstawie oświadczenia o zamiarze powierzenia pracy), w którym w ciągu zaledwie kilku lat (od 2007 roku) uczestniczyło kilkaset tysięcy mieszkańców Białorusi, Rosji, Ukrainy, Mołdowy, a od listopada 2009 roku także Gruzji. Wskazuje to z jednej strony na zainteresowanie Polską jako krajem migracji zarobkowej, a z drugiej na duże potrzeby polskiej gospodarki.

\section{Imigranci spoza UE w Lodzi i regionie lódzkim}

\section{Pracujący}

Według danych NSP $2011 \mathrm{w}$ województwie łódzkim mieszkało prawie 2,3 tys. imigrantów spoza UE. Liczba cudzoziemców w regionie łódzkim, podobnie jak i w innych częściach kraju, wzrosła w ostatniej dekadzie. Nie zmienia to jednak faktu, że mimo wzrostu, w łódzkiem przebywa osiem razy mniej cudzoziemców niż w regionie stołecznym (województwo mazowieckie). Także regiony innych wielkich miast Polski - Poznania, Wrocławia, Krakowa, Katowic i Gdańska gromadziły więcej cudzoziemców niż województwo łódzkie. Region łódzki nie należy do głównych obszarów koncentracji imigrantów w Polsce.

Stosunkowo niewielki był w badanym regionie udział pracujących imigrantów. Pod względem liczby wydanych pozwoleń na pracę, region łódzki zajmował w 2009 roku ósme miejsce w kraju. Najwięcej, przeszło 10-krotnie takich pozwoleń, wydawano w województwie mazowieckim, głównie w Warszawie.

Cudzoziemcy koncentrują się głównie w Łodzi i jej obszarze metropolitalnym (przede wszystkim w Pabianicach i Zgierzu). Region nasz powiela schemat występujący w innych częściach Polski, w którym gros cudzoziemców koncentruje się w największych miastach regionów. Poza łódzkim obszarem metropolitalnym, miejscami koncentracji cudzoziemców są średnie miasta: Piotrków Trybunalski oraz Bełchatów. To drugie miasto, z uwagi na lokalizację największej w Polsce 
kopalni węgla brunatnego oraz elektrowni, jest miejscem koncentracji wykwalifikowanej siły roboczej z zagranicy.

Struktura narodowościowa imigrantów spoza UE przebywających w regionie jest podobna jak w całej Polsce - najliczniej reprezentowani są przybysze z Ukrainy ( $25 \%$ ogółu imigrantów), Białorusi i innych byłych krajów socjalistycznych oraz z Azji (w tym Chińczycy 10\% ogółu). Podobnie też, jak i w reszcie kraju, wśród imigrantów spoza UE przebywających w regionie łódzkim przeważały osoby zatrudnione na stanowiskach nie wymagających wysokich kwalifikacji. Imigranci przebywający w regionie łódzkim, w zależności od kraju pochodzenia, pracowali głównie w rolnictwie, przemyśle wytwórczym, budownictwie i handlu.

W latach 2012-2013 w zezwoleniach na pracę w regionie lódzkim, jak i w Polsce, dominowało rolnictwo. Każda z pięciu najliczniej prezentowanych nacji miała największy udział w tym sektorze. Najliczniejszą grupą byli Ukraińcy. $\mathrm{Na}$ drugim miejscu byli pracownicy zatrudnieni w gospodarstwach domowych (opieka nad dziećmi i osobami starszymi oraz sprzątanie mieszkań). To również okazało się domeną Ukraińców, podobnie jak praca w budownictwie i przetwórstwie przemysłowym, handlu, transporcie i opiece zdrowotnej. W gastronomii dominowali Wietnamczycy, zaś w finansach i ubezpieczeniach Chińczycy (tab. 4).

W regionie łódzkim działają firmy, które zatrudniają obcokrajowców, zarówno polskie, zagraniczne, jak i należące do kapitału mieszanego. Prezentowany w pracy projekt unijny DIVERS PROJECT obligował jego zespół do przeprowadzenia szczegółowych wywiadów w 10 przedsiębiorstwach i instytucjach zatrudniających cudzoziemców spoza UE oraz w wybranych organizacjach pozarządowych. $\mathrm{W}$ badaniach pierwszej grupy należało uwzględnić instytucje publiczne, profit i non-profit. Wytypowano podmioty publiczne reprezentowane przez wyższą uczelnię i urząd administracji publicznej, duże korporacje ponadnarodowe z udziałem kapitału zagranicznego, mniejsze przedsiębiorstwa typu profit i stowarzyszenia non profit.

Proces zbierania danych obejmował kilka etapów. W pierwszym złożono wizytę i powiadomiono władze województwa łódzkiego o realizowanym projekcie. Wicewojewoda łódzki wystawił zespołowi rekomendację do osób i instytucji o wzięcie udziału w projekcie, jego celowości oraz wskazał osoby upoważnione do prowadzenia badań. Etap drugi polegał na wyłonieniu instytucji zatrudniających imigrantów spoza UE w województwie łódzkim. W trzecim etapie odbyto rozmowy telefoniczne z pracownikami HR w danej firmie, a następnie przesłano im informacje o projekcie i dyspozycje do wywiadu swobodnego. Kwestionariusz wywiadu zawierał 41 pytań, które dotyczyły oprócz ogólnej charakterystyki zakładu, liczby pracowników, zatrudnionych cudzoziemców spoza UE - krajów ich pochodzenia, zajmowanych stanowisk, sposobów rekrutacji oraz praktykowanych w firmie sposobów zarządzania różnorodnością (czyli zarządzania międzynarodowym zespołem pracowników). Nie prowadzono wywiadów z cudzoziemskimi pracownikami. 
Tabela 4

Zezwolenia na pracę dla cudzoziemców według obywatelstwa i wybranych sekcji gospodarki w regionie łódzkim w latach 2012-2013

\begin{tabular}{|c|c|c|c|c|c|c|}
\hline Branża & $\begin{array}{l}\text { Ogółem } \\
\text { region }\end{array}$ & Ukraina & Chorwacja & Chiny & Wietnam & Uzbekistan \\
\hline $\begin{array}{l}\text { Rolnictwo, } \\
\text { leśnictwo, łowie- } \\
\text { ctwo i rybactwo }\end{array}$ & 1796 & 502 & 280 & 109 & 97 & 94 \\
\hline Budownictwo & 42 & 38 & 0 & 0 & 0 & 1 \\
\hline $\begin{array}{l}\text { Przetwórstwo } \\
\text { przemysłowe }\end{array}$ & 272 & 109 & 0 & 18 & 0 & 86 \\
\hline $\begin{array}{l}\text { Handel hurtowy } \\
\text { i detaliczny }\end{array}$ & 66 & 55 & 0 & 1 & 0 & 0 \\
\hline $\begin{array}{l}\text { Gospodarstwa } \\
\text { domowe zatrud- } \\
\text { niające pracow- } \\
\text { ników }\end{array}$ & 319 & 43 & 0 & 21 & 22 & 2 \\
\hline $\begin{array}{l}\text { Transport } \\
\text { i gospodarka } \\
\text { magazynowa }\end{array}$ & 63 & 25 & 0 & 0 & 0 & 0 \\
\hline $\begin{array}{l}\text { Zakwaterowanie } \\
\text { i gastronomia }\end{array}$ & 142 & 17 & 0 & 7 & 65 & 0 \\
\hline $\begin{array}{l}\text { Działalność } \\
\text { profesjonalna, } \\
\text { naukowa, } \\
\text { techniczna }\end{array}$ & 8 & 0 & 0 & 0 & 0 & 0 \\
\hline $\begin{array}{l}\text { Informacja, } \\
\text { komunikacja }\end{array}$ & 4 & 2 & 0 & 0 & 0 & 0 \\
\hline $\begin{array}{l}\text { Działalność } \\
\text { finansowa, } \\
\text { ubezpieczenia }\end{array}$ & 139 & 11 & 0 & 46 & 0 & 0 \\
\hline $\begin{array}{l}\text { Opieka zdrowotna, } \\
\text { pomoc społeczna }\end{array}$ & 52 & 37 & 0 & 0 & 0 & 0 \\
\hline Edukacja & 15 & 1 & 0 & 2 & 0 & 0 \\
\hline
\end{tabular}

Źródło: Ministerstwo Pracy i Polityki Społecznej.

Metodą badań był wywiad swobodny, a narzędziem badawczym dyspozycje do wywiadu. Firmy, które wyraziły zgodę na udział w projekcie przeszły do etapu czwartego, w czasie którego złożono w nich wizytę w celu przeprowadzenia badań wg wcześniej przygotowanego i przesłanego kwestionariusza. 
Z instytucji publicznych do badań włączono Uniwersytet Łódzki, uczelnię, która zatrudnia najwięcej cudzoziemców spoza UE spośród łódzkich uczelni i należy do grona największych pracodawców w województwie łódzkim oraz Urząd Miasta Łodzi. Pozostałe instytucje publiczne nie zatrudniają cudzoziemców spoza UE. Poza instytucjami publicznymi wybrano do badań pięć przedsiębiorstw typu profit oraz trzy placówki non-profit.

Wyselekcjonowane do badań jednostki to:

- instytucje publiczne:

1. Uniwersytet Łódzki,

2. Urząd Miasta Łodzi;

- przedsiębiorstwa typu profit:

1. Flextronics Logistics Sp. z o.o.,

2. Sonoco Poland - Packing Services Sp. z o.o.,

3. Przedsiębiorstwo Usługowe Hatrans Sp. z o.o.,

4. Sharda Europe Co. Ltd. w Pabianicach,

5. ABB SP. z o.o., Zakład w Aleksandrowie Łódzkim;

- instytucje typu non-profit:

1. Regionalna Izba Gospodarcza (RIG),

2. Stowarzyszenie dla Osób Rosyjskojęzycznych (SOR),

3. Stowarzyszenie Polsko-Libańskie (SPL).

Jak wykazały badania, w wytypowanych $\mathrm{w}$ regionie łódzkim przedsiębiorstwach/instytucjach pracowało w sumie zaledwie 90 pracowników spoza UE, w tym 26 kobiet i 64 mężczyzn. Najstarsze osoby pracowały w Uniwersytecie Łódzkim na stanowiskach profesorów (ogółem 17 osób), natomiast najmłodsze w Regionalnej Izbie Gospodarczej. Cała 90 osobowa grupa imigrantów pochodziła z 22 państw świata. Najbardziej zróżnicowani pod względem narodowości imigranci spoza UE pracowali w UŁ. Reprezentowali oni 9 państw, lecz najwięcej pracowników okazało się obywatelami Ukrainy. W sumie 33 imigrantów spoza UE mieszkało w Europie, 27 w Afryce, 26 w Azji i jedynie 4 pochodziło z Ameryki Północnej i Środkowej (tab. 5).

W międzynarodowych firmach typu profit zarządzanie różnorodnością stanowi powszechnie znany $\mathrm{i}$ istotny element prowadzonej polityki zatrudnienia, a migracja pracowników, w tym spoza UE wynika m.in. z polityki korporacyjnej. Wszystkie przedsiębiorstwa typu profit zadeklarowały, że będą rozwijać zarządzanie różnorodnością. W pozostałych instytucjach typu public i non-profit zarządzanie różnorodnością nie miało umocowań organizacyjnych, nie funkcjonowało w ich dokumentach, co nie oznacza, że nie było stosowane.

Okazało się, że wszystkie przebadane instytucje/przedsiębiorstwa prowadzą dobrą i przejrzystą politykę rekrutacyjną, która owocuje przyjmowaniem do pracy osób różnej narodowości, religii, płci i wieku. Pozyskiwanie do pracy cudzoziemców przez firmy odbywa się poprzez ogłoszenia w różnych językach na portalach 
Tabela 5

Kraje pochodzenia zatrudnionych w badanych przedsiębiorstwach/instytucjach regionu łódzkiego imigrantów spoza UE w 2014 roku

\begin{tabular}{|c|c|c|c|c|c|c|c|c|c|c|c|c|c|c|c|c|c|c|c|c|c|c|c|}
\hline \multirow[b]{2}{*}{$\begin{array}{c}\text { Typ } \\
\text { orga- } \\
\text { nizacji }\end{array}$} & \multirow[b]{2}{*}{$\begin{array}{l}\text { Liczba } \\
\text { imi- } \\
\text { grantów }\end{array}$} & \multicolumn{22}{|c|}{ Obywatelstwo imigrantów spoza UE: } \\
\hline & & $\begin{array}{l}\frac{\pi}{8} \\
00 \\
\frac{0}{4}\end{array}$ & 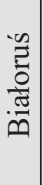 & 离 & $\stackrel{0}{=}$ & 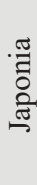 & : & 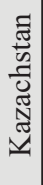 & טֶّ & 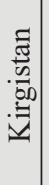 & 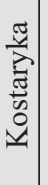 & $\begin{array}{l}\cdot \frac{\pi}{\vec{D}} \\
.000 \\
\vec{Z}\end{array}$ & 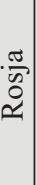 & 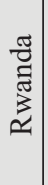 & $\begin{array}{l}. \frac{\pi}{0} \\
\frac{0}{0} \\
\tilde{D}\end{array}$ & 蚝 & 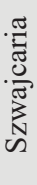 & 奈 & 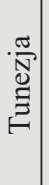 & 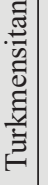 & 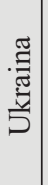 & $\underset{\sim}{\overparen{\sim}}$ & 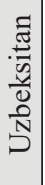 \\
\hline \multicolumn{24}{|c|}{ Public } \\
\hline $\mathrm{U} \mathrm{U}$ & 17 & & & 1 & & 1 & & & & 1 & 1 & & 3 & & 2 & & & & & & 5 & 2 & 1 \\
\hline UME & 1 & & & & & 1 & & & & & & & & & & & & & & & & & \\
\hline \multicolumn{24}{|c|}{ Profit } \\
\hline ABB & 1 & & & & & & & & & & & & & & & & 1 & & & & & & \\
\hline Flextronic & 10 & & & & & & & & & & & & & & & & & 10 & & & & & \\
\hline Hatrans & 1 & & & & & & & & & & & & & & & & & & & & 1 & & \\
\hline Sharda & 2 & & & & 2 & & & & & & & & & & & & & & & & & & \\
\hline Sonoco & 4 & & & & & & & & & & & 2 & & & & & & & 1 & & & 1 & \\
\hline \multicolumn{24}{|c|}{ Non-profit } \\
\hline RIG & 5 & 1 & & & & & & & 1 & & & & & 2 & & 1 & & & & & & & \\
\hline SOR & 29 & & 8 & & & & & 7 & & & & & & & & & & & & 1 & 13 & & \\
\hline SPL & 20 & & & & & & 20 & & & & & & & & & & & & & & & & \\
\hline Razem & 90 & 1 & 8 & 1 & 2 & 2 & 20 & 7 & 1 & 1 & 1 & 2 & 3 & 2 & 2 & 1 & 1 & 10 & 1 & 1 & 19 & 3 & 1 \\
\hline
\end{tabular}

Źródło: opracowanie własne.

rekrutacyjnych oraz korzystanie z programu umożliwiającego międzynarodową mobilność pracownika (Global Mobility).

Dobrze rozbudowany system szkoleń zapewnia nie tylko przygotowanie do wykonywanej czynności, zajmowanego stanowiska, ale przede wszystkim wprowadza imigrantów w środowisko pracy panujące w firmie. Każda instytucja kultywuje swoje wartości, przestrzega kodeksu etycznego czy kodeksu postępowania. We wszystkich jednostkach prowadzony jest dwustronny charakter komunikacji - władze wsłuchują się w opinie pracowników, prowadzą dialog z wewnętrznym środowiskiem. Sprzyja to budowie wspólnoty, a także powoduje, że pracownicy utożsamiają się ze swoją firmą. Pracownikom cudzoziemskim w firmach umożliwia się obchodzenie ich własnych świąt religijnych lub narodowych (wolny dzień).

Do dobrych praktyk w zakresie zarządzania różnorodnością, wskazanych przez wszystkie badane przedsiębiorstwa, zaliczyć trzeba transparentny sposób wynagradzania pracowników, oparty na obiektywnych miernikach. Najczęściej 
firmy wyróżniały mierniki: ilościowe oparte o konkretne założenia liczbowe (np. osiągnięcie sprzedaży $\mathrm{w}$ danym okresie na określonym poziomie); projektowe - dotyczyły wdrożenia procesu lub systemu; jakościowe - związane z wykonywaniem obowiązków i celów (terminowość, dokładność, przestrzeganie obowiązujących procedur), z prezentowaniem odpowiedniej postawy (praca zespołowa, aktywne działanie, nastawienie na szukanie rozwiązań, kreatywność).

\section{Członkowie organizacji pozarządowych}

Drugą zbadaną grupą $\mathrm{w}$ projekcie stali się imigranci spoza UE udzielający się w wybranych organizacjach pozarządowych. Proces zbierania danych przebiegał w kilku fazach. Pierwszą z nich było sprawdzenie, jaka liczba i jakich organizacji pozarządowych zlokalizowana jest na terenie województwa łódzkiego oraz w Łodzi. W drugiej fazie przeprowadzono wspomagany komputerowo wywiad telefoniczny, który pozwolił wyłonić organizacje z czynnie uczestniczącymi w nich imigrantami spoza UE. Na tym etapie napotkano na przeszkody w dotarciu do niektórych organizacji. Najczęstszą przeszkodą był brak kontaktu telefonicznego lub elektronicznego (e-mailowego) z siedzibą organizacji, brak odpowiedzi na kontakt telefoniczny lub mailowy, odmowa udzielenia odpowiedzi na zadawane pytania lub zaprzestanie działalności bez jego zgłoszenia organom nadrzędnym. Okazało się także, że tylko nieliczne organizacje posiadają wśród swoich członków, wolontariuszy czy innych działaczy - imigrantów spoza UE czy też obcokrajowców w ogóle. Grupę organizacji pozarządowych, które spełniały postawiony warunek zakwalifikowano do trzeciej fazy badania, czyli przeprowadzenia wywiadu swobodnego ukierunkowanego, w którym podstawę stanowiły pytania dotyczące uczestnictwa obywateli imigrantów w strukturze i działaniach organizacji.

Tylko osiem organizacji zgodziło się na uczestnictwo w badaniu i upublicznienie jego wyników przechodząc do trzeciej fazy badań. Były to: Białoruski Dom, Rotary Club Łódź, Związek Ukraińców w Polsce Koło Łódź, Stowarzyszenie Studentów Muzułmańskich i Liga Muzułmańska PR - Łódź, Stowarzyszenie Pomocy Repatriantom, Zrzeszenie Użytkowników Parkingu Strzeżonego Łódź-Widzew, Fabryka Równości oraz Sobór św. Aleksandra Newskiego w Łodzi. Część rozmówców (szczególnie z niższych szczebli struktury organizacyjnej i wolontariuszy) pragnęła pozostać anonimowa ze względu na specyfikę działalności organizacji i powszechny brak tolerancji społecznej dotykający osoby korzystające z pomocy stowarzyszenia.

Badania wykazały, że imigranci spoza UE należeli najczęściej do stowarzyszeń i organizacji etnicznych. Nastawieni byli na ogół na podtrzymywanie tradycji i kultury w swoim gronie. Szukali najczęściej pomocy dla siebie, nie udzielając się dla innych. Prawosławni najczęściej pierwsze kroki kierowali do działającej w Łodzi od XIX wieku cerkwi. 
Do podstawowych problemów wskazywanych przez respondentów należały te związane z poszukiwaniem mieszkania i pracy oraz zawieraniem umów najmu mieszkania i umów o pracę. Często imigranci nie znający dobrze języka i polskiej rzeczywistości byli oszukiwani przez pracodawców. Ich wynagrodzenia zaniżano, pozbawiano także ubezpieczenia czy świadczeń socjalnych. Często traktowano ich jak „obywateli drugiej kategorii”. Rolą stowarzyszenia wówczas było wskazanie odpowiednich organów państwa, do których można się zwrócić lub przedstawienie innych rozwiązań satysfakcjonujących imigranta. Dla imigrantów, którzy w Polsce mieszkali już dłuższy czas i nie borykali się z takimi podstawowymi problemami, uczestnictwo w działaniach stowarzyszeń etnicznych miało na celu przede wszystkim kultywowanie tradycji narodowych, podtrzymywanie kultury czy pielęgnowanie języka.

$\mathrm{W}$ organizacjach nieetnicznych zrzeszali się i działali imigranci lepiej wykształceni, nastawieni na stały pobyt. Często szukali kontaktów z Polakami, co wynikało z faktu, że obcokrajowcy nie posiadający obywatelstwa polskiego nie mogą, w odróżnieniu do Polaków, zakładać stowarzyszeń. Cudzoziemcy posiadający miejsce zamieszkania w Polsce mieli prawo do zrzeszania się, pozostałym zaś takie prawo przysługiwało tylko wtedy, gdy przewidywał taką możliwość statut danej organizacji.

Aktywność imigrantów spoza UE w organizacjach pozarządowych w Polsce, ale również $\mathrm{w}$ regionie łódzkim była bardzo mała. W pracę na rzecz stowarzyszeń najczęściej angażowali się imigranci nastawieni na pobyt stały, młodzi, z wyższym wykształceniem i stałą pracą, wysokimi kompetencjami zawodowymi i zadowoleni z własnego życia.

\section{Podsumowanie}

Przeprowadzone w ramach grantu badania pozwoliły stwierdzić, iż w Łodzi i regionie łódzkim jest niewielu imigrantów spoza UE, podobnie jak niewiele przedsiębiorstw /instytucji zatrudnia takie osoby. W przebadanych przedsiębiorstwach/ instytucjach zatrudniających imigrantów przestrzega się zasad zarządzania różnorodnością choć nie zawsze jest to działanie sformalizowane. Gorzej jest, jak wynika z wywiadów z imigrantami należącymi do organizacji pozarządowych, u pracodawców prywatnych.

Mała liczba imigrantów w całej Polsce $(0,3 \%$ ogółu ludności) nie stymuluje prac nad projektowaniem i testowaniem nowych rozwiązań instytucjonalnych dotyczących imigrantów. Wobec aktualnych potrzeb w sytuacji demograficznej starzejącego się społeczeństwa polskiego, jak również takich czynników zewnętrznych jak niestabilna sytuacja polityczna i kryzys gospodarczy na Ukrainie, spodziewany jest większy napływ imigrantów spoza UE. Wielu pracodawców 
zgłasza zapotrzebowanie na pracowników z Ukrainy. Trzeba wobec tego przemyśleć politykę imigracyjną, zwłaszcza w stosunku do Ukraińców - najbliższych sąsiadów, szybko asymilujących się w Polsce i dobrze postrzeganych przez Polaków. W takiej sytuacji najważniejszym postulatem jest udoskonalenie istniejących przepisów prawnych oraz stworzenie nowych regulujących w lepszy sposób problemy pobytu i pozyskiwania pracy w Polsce przez cudzoziemców.

Istniejące przepisy prawne regulujące pracę imigrantów nie są doskonałe. Słabą stroną obecnych rozwiązań prawnych są możliwości zatrudnienia cudzoziemców spoza UE w zawodach regulowanych. Żaden przepis nie określa ani szczegółowo ani ogólnie zasad uznawania kwalifikacji zawodowych tych pracowników. Ustawodawca powinien szybko pomyśleć nad wypełnieniem istniejącej luki prawnej. Może wzorem pracowników będących obywatelami UE należałoby dopuścić do uznawania niektórych kwalifikacji zawodowych w drodze uproszczonego testu umiejętności. Bardzo ważnym problemem jest kontynuacja kwalifikacji uzyskanych w swoim państwie (teraz tylko skorzystać mogą z tego pracownicy z UE). Należałoby prawo to rozciągać na wszystkich imigrantów ubiegających się o pracę.

Badani imigranci wskazywali na trudności dotyczące legalizacji pobytu, czy długotrwałych procedur uznawania kwalifikacji. Ich stowarzyszenia wskazują na niewłaściwe praktyki, np. niezawieranie umów na piśmie czy nadużycia ze strony działających nielegalnie pośredników. Niektóre stowarzyszenia postulują tzw. zezwolenia sektorowe, czyli dające możliwość swobodniej zmiany pracodawcy $\mathrm{w}$ danym sektorze. Obecnie zmiana pracodawcy wiąże się z utratą pozwolenia na pracę dla większości z nich.

Wprowadzenie zezwoleń sektorowych - na pracę w jednym sektorze, ale z możliwością zmiany pracodawcy - powinno przyczynić się do mobilności zawodowej imigrantów spoza UE na polskim rynku pracy, a także wzmocnić ich pozycję wobec pracodawców. Rozwiązania formalne w kwestii zatrudniania ich w zawodach regulowanych są niezbędne w celu otworzenia wielu zawodów. Zabieg ten jest konieczny w celu umożliwienia szerszego uznawania wiedzy, umiejętności i kompetencji tych pracowników.

Bardzo często imigrant pracujący w Polsce załatwiający swoje sprawy w urzędach ma trudności językowe. Brak jest odpowiednich dokumentów w językach imigrantów czy też dokumentów w europejskich językach konferencyjnych (najlepiej w języku angielskim). Z pewnością przydałoby się w wielu urzędach stanowisko konsultanta do spraw cudzoziemców, który wyjaśniłby, najlepiej w obcym języku, wszystkie zawiłości prawa pracy, wymaganych dokumentów i procedur.

W przypadku rozwiązań prawnych możliwe usprawnienia powinny dotyczyć trzech zasadniczych kwestii: czasu na jaki wydawane jest zezwolenie, wprowadzenia zezwoleń sektorowych na pracę, unormowania kwestii wykonywania zawodów regulowanych przez imigrantów spoza UE (zwłaszcza w przypadku 
najliczniejszej grupy imigrantów - Ukraińców). Wydłużenie okresu na jaki wydawane są zezwolenia na pracę pozwoli imigrantom na lepszy rozwój zawodowy - wyniki badań wskazują, że pracodawcy nie chcą inwestować w szkolenia zatrudnionych na krótki okres. Wprowadzenie zezwoleń sektorowych na pracę $\mathrm{w}$ jednym sektorze, ale z możliwością zmiany pracodawcy powinno przyczynić się do mobilności zawodowej imigrantów na polskim rynku pracy, a także wzmocnić ich pozycję wobec pracodawców. Rozwiązania formalne w kwestii zatrudniania imigrantów w zawodach regulowanych są niezbędne w celu otworzenia wielu zawodów.

Należy powszechnie zastosować istniejące już prawo 6 miesięcy pracy w ciągu 12 miesięcy dla wszystkich chętnych słabiej wykwalifikowanych cudzoziemców. Jak do tej pory z prawa tego mogą jedynie skorzystać obywatele Ukrainy, Białorusi i Rosji.

Sami imigranci najsilniej postulują stworzenie możliwości, by mogli starać się o pracę samemu, czyli odpowiadać na ofertę pracy oraz wprowadzenie zezwoleń sektorowych na pracę w ramach określonego sektora gospodarki. Teraz po utracie pracy trzeba ponownie starać się o pozwolenie.

Trzeba kontynuować i prowadzić nowe badania, dzięki którym rozpoznana zostanie sytuacja imigrantów na polskim i regionalnym rynku pracy. Istniejące badania dotyczą obecności imigrantów spoza UE na polskim rynku pracy i odnoszą się przede wszystkim do analiz wielkości napływu oraz struktury zatrudnienia cudzoziemców, konkretnych grup cudzoziemców bądź ogólnych warunków zatrudnienia. Brakuje opracowań naukowych i raportów dotyczących konkretnych sektorów gospodarki, jak również szczegółowych prac poświęconych wąskiemu zagadnieniu, jakim jest rozpoznawanie umiejętności, wiedzy i kompetencji imigrantów.

\section{LITERATURA}

Biuletyn Migracyjny nr 41 z kwietnia 2013, Ośrodek Badań nad Migracjami, Uniwersytet Warszawski, Warszawa.

Biuletyn Migracyjny nr 54 z czerwca 2016, Ośrodek Badań nad Migracjami, Uniwersytet Warszawski, Warszawa.

Brunarska Z., Grotte M., Lesińska M., 2012, Migracje obywateli Ukrainy do Polski w kontekście rozwoju społeczno-gospodarczego: stan obecny, polityka transfery pieniężne, Ośrodek Badań nad Migracjami, Warszawa.

Duszczyk M., 2012, Polska polityka migracyjna a rynek pracy, Instytut Polityki Społecznej, UW, Warszawa.

Golinowska S. (red.), 2004, Popyt na pracę cudzoziemców. Polska i sąsiedzi, IPiSS, Studia i Materiały, Warszawa.

Górny A., Grabowska-Lusińska I., Lesińska M., Okólski M. (red.), 2010, Transformacja nieoczywista. Polska jako kraj imigracji, Wydawnictwa Uniwersytetu Warszawskiego, Warszawa. 
Grzymała-Kazłowska A., 2002, Wpływ migracji zagranicznych $w$ Warszawie na sytuacje na stołecznym rynku pracy, Prace Migracyjne nr 44, Warszawa.

Halik T., Nowicka E., 2002, Wietnamczycy w Polsce. Izolacja czy integracja, Instytut Orientalistyczny, Warszawa.

Jakóbczyk-Gryszkiewicz J., Marcińczak S., Sztybel-Boberek M., Wolaniuk A., 2015, Poland - Immigrants in a New Immigrant Country. Institutions, Society, Economy and TCNs in Łódź [w:] Zanfrini L. (red.), The Diversity Value. How to Reinvent the European Approach to Immigration, Mc Graw - Hill Education, s. 239-250.

Klaus W. (red.), 2011, Ziemia obiecana. Warunki pracy cudzoziemców w Polsce, Fundacja im. S. Batorego.

Kloc-Nowak W., 2007, Funkcjonowanie imigrantek z Ukrainy na polskim rynku pracy - sytuacja obecna i rekomendacje dla społeczeństwa przyjmujacego, Stowarzyszenie Interwencji Prawnych, Warszawa.

Klorek N., Szulecka M., 2013, Migranckie instytucje ekonomiczne i ich wptyw na otoczenie. Przykład centrów handlowych w Wólce Kosowskiej, Stowarzyszenie Interwencji Prawnych, Warszawa.

Konieczna-Sałamatin J., 2015, Imigracja do Polski w świetle danych urzędowych, Centrum Obsługi Projektów Europejskich Ministerstwa Spraw Wewnętrznych, Warszawa.

Korczyńska J., Duszczyk M., 2005, Zapotrzebowanie na pracę obcokrajowców w Polsce - próba analizy $i$ wniosków dla polityki migracyjnej, Warszawa.

Okólski M., 2011, Polska jako kraj imigracji-wprowadzenie, [w:] Górny A., Grabowska-Lusińska I., Lesińska M., Okólski M. (red.), Transformacja nieoczywista. Polska jako kraj imigracji, Wydawnictwa Uniwersytetu Warszawskiego, Warszawa.

Polakowski M., 2010, Imigranci z krajów trzecich na polskim rynku pracy, Warszawa.

Raport. Imigranci z Ukrainy ratunkiem dla polskiej demografii, 2016, Związek Przedsiębiorców i Pracodawców, Warszawa.

Zarządzanie różnorodnościa w miejscu pracy. Raport z I edycji Barometru Różnorodności, 2014, Diversity Index.

\section{THIRD COUNTRY NATIONALS IN POLAND, LÓDŹ AND LÓDŹ REGION}

Abstract The paper presents the results of a research project carried out in Łódź and the Łódź region under EU grant Diversity Improvement as a Viable Enrichment Resource for Society and Economy. The research was conducted in various institutions dealing with foreigners in Poland and in the region, in enterprises employing immigrants (public, for-profit and not-for-profit), and in voluntary organizations with which such persons are involved.

The purpose of the project was to find out if there is an effectively functioning model in Poland and in the region for Third Country Nationals (TCNs) integration, and if any practices have been adopted to support their equal treatment and effective valorisation of their skills, knowledge and competence.

The presence of TNCs in the Łódź region is only marginal. They are mostly staying in Łódź and its metropolitan area. Their nationality structure has been found to be similar to that of the country as a whole - the most numerous are immigrants from Ukraine $(25 \%$ of the total number of 
immigrants), Belarus and other former socialist countries, and from Asia (Chinese constituting $10 \%$ of their total number). The majority of the immigrants are employed in positions which do not require high qualifications. Those staying in the Łódź region are mainly working in manufacturing, construction and trade, depending on their country of origin.

In view of the present demographic situation of the aging Polish society and considering external factors such as the war and economic crisis in Ukraine, an increased inflow of TCNs should be expected.

Keywords Immigrants, Third Country Nationals, integration, immigrants' skills, knowledge and competence, EU, Poland, Łódź, the Łódź region.

Prof. dr hab. Jolanta Jakóbczyk-Gryszkiewicz Instytut Geografii Miast i Turyzmu Wydział Nauk Geograficznych Uniwersytet Lódzki 